\title{
Kiwifruit Yield Efficiency, Plant Density, and Bud Number per Surface Unit
}

\author{
Raffaele Testolin \\ Istituto di Produzione Vegetale, Universitá di Udine, 33100 Udine, Italy \\ Additional index words. crop modelling, orchard design, training, in-row spacing, pruning, Actinidia deliciosa
}

\begin{abstract}
Kiwifruit [Actinidia deliciosa (A. Chev.) C.F. Liang et A.R. Ferguson] crop response to variations in plant density and bud number per surface unit of growing area was studied to determine optimum levels of these factors. Five bud numbers per surface unit $(50,000,100,000,150,000 ; 200,000$, and 250,000 mixed buds/ha) and four plant densities, obtained by varying the in-row spacings $(1.5,3.0,4.5$, and $6.0 \mathrm{~m})$, were combined in a factorial design and tested in a kiwifruit orchard during two growing seasons on the same vines. Kiwifruit yield increased from 7 to 24 t•ha ${ }^{-1}$ with increasing bud number per hectare according to a 2 nd-order polynomial function. Both the reduction in the mean fruit mass as well as the percentage budbreak caused a decrease in orchard efficiency. No differences between 1.5- and 3.0-m in-row spacings were found; spacings wider than $3.0 \mathrm{~m}$ reduced crop efficiency principally by decreasing fruit mass.
\end{abstract}

Kiwifruit yield per SU depends on the number of buds, budbreak proportion, number of fruits per fruitful shoot, and mean fruit mass (Buwalda and Smith, 1988). The last three factors are influenced by the bud number per SU and by other exogenous factors, such as environment, cultural practices, and pollination. The bud number per SU is a product of three factors: 1) the number of vines per SU, 2) the number of canes per vine, and 3) the number of buds per cane. Variations in the total number of buds per hectare can be obtained by using various combinations of the above.

Maximum yield was achieved for kiwifruit in Italy with $\approx 280,000$ buds/ha (Testolin et al., 1988). Nevertheless, the yield gain above 200,000 buds/ha was negligible because of decreasing orchard efficiency due to a reduction in the mean fruit mass and bud fruitfulness (Testolin et al., 1988).

The percentage of fruitful budbreak and the number of fruits per shoot slightly decline as the number of buds per cane increases (Costa et al., 1987; Giorgio et al., 1987; Testolin et al., $1985,1988)$, whereas no differences in mean fruit mass related to bud load per cane were found (Blanchet, 1986; Giorgio et al., 1987), except by Costa et al. (1987).

Insofar as the bud efficiency decreases at increasing mixed buds per cane, short canes would be expected to be the most efficient. However, this is not true if all the buds of the cane are taken into consideration. The presence of the basal flatish buds, which produce only vegetative shoots on short canes, results in a low fruitfulness because they constitute a higher proportion of total buds. If the entire cane is considered, the highest efficiency per mixed bud is attained by 12-node-long canes (Giorgio et al., 1987). Analogous conclusions can be drawn for canes that fruited the previous season because nodes that bore fruit the previous year and occupy the basal portion of the cane are unproductive (Brundell, 1975; Linsley-Noakes and Allan, 1987; Snelgar, 1988; Snowball and Considine, 1986).

Objectives of this study were to determine the most suitable bud number per SU in kiwifruit and the optimal level of one (plant density) of the three factors that contribute to the bud number per SU.

Received for publication 24 May 1989. The research was supported by the Ministry of Education-Special Grant $40 \%$. The cost of publishing this paper was defrayed in part by the payment of page charges. Under postal regulations, this paper therefore must be hereby marked advertisement solely to indicate this fact.

\section{Materials and Methods}

The trial was carried out in 1987 and 1988 in an experimental orchard at Cittadella, Padova (lat. $45^{\circ} 38^{\prime} \mathrm{N}$ ), Italy, where vines of 'Hayward' kiwifruit were grown from 1982 as rooted cuttings at 1.5-, 3.0-, 4.5-, and 6. O-m in-row spacings and $4.5 \mathrm{~m}$ between rows. These distances corresponded to plant densities of 1481, 741, 494, and 370 vines/ha, respectively. A 7 female : 1 male ratio was used by planting 'Matua' male vines every fourth plant in every second row.

For each in-row spacing, 50,000, 100,000, 150,000, 200,000, and 250,000 mixed buds/ha were compared using a factorial arrangement. A split-plot design was adopted, with spacings in plots and bud numbers in sub-plots of one vine. The plots were replicated in five randomized blocks. The five female vines of each plot were first classified according to their position in regard to the nearest pollenizer. The five vines within the same treatment represented all five positions with regard to the nearest pollenizer. This stratified sampling (Snedecor and Cochran, 1980) was more appropriate than random sampling because the effect of the position with regard to the pollenizer was considered of greater importance than other environmental factors.

Vines were trained to a T-bar with 2-m-wide cross arms. Replacement canes were shortened to 12 mixed buds, counted, thinned to achieve the stated bud load per hectare, and tied to the wire running at the end of the cross arms. Soil management consisted of mowing a permanent grass and clover sward. Fertilizers $(\approx 50 \mathrm{t}$ of strawy manure, $16 \mathrm{~kg}$ of $\mathrm{N}, 48 \mathrm{~kg}$ of both $\mathrm{P}$ and $\mathrm{K} / \mathrm{ha}$ per year) were applied uniformly over the whole experimental orchard. Water was supplied from April to September by restoring $100 \%$ of crop reference evapotranspiration (ET) measured with a Class A Pan and corrected for wind speed and relative humidity conditions (Doorenbos and Pruitt, 1977) when a 10-mm deficit was reached. Water was distributed using microsprinklers with 360 " wetting patterns placed every $4.5 \mathrm{~m}$ in the row (Testolin et al., 1987).

At winter pruning, four canes in each vine were tagged. Buds were counted on each cane, excluding basal flatish buds in unfruited canes, starting from the first mixed bud following the last axil that had born fruit the previous year in fruited canes. At the appropriate time during the growing season, observations on the percentages of fruiting and vegetative shoots and number

Abbreviations: SU, surface unit of growing area. 
of floral corymbs, flowers, and fruits were made. Yield and mean fruit mass of 100 fruits also were recorded from each vine.

Analysis of variance was carried out by considering years as sub-sub-plots.

\section{Results and Discussion}

The increase in bud number per SU from 50,000 to $250,000 /$ ha increased yield from $\approx 7$ to $\approx$ ' $24 \mathrm{t} \cdot \mathrm{ha}^{-1}$ according to a 2nd-order polynomial function (Fig. 1). The equation was fitted to the mean data of all the in-row spacings and both years. There were no interactions between bud number and other factors. By extrapolating from the fitted equation, maximum yield (25.8 t.ha-') should be achieved with 333,000 buds/ha.

The fruit yield .(Y) resulted in a nonlinear response to bud density (BD), where dY/dBD decreased with increasing BD. The loss in efficiency resulted from the cumulative effect of a reduction in fruit mass and number produced per winter bud.

Mean fruit mass decreased by $0.08 \mathrm{~g}$ for each increase of 1000 buds/ha (Fig. 2). Because mean fruit mass and number of seeds per fruit are correlated (Clinch, 1984; D'Ambrosio et al., 1986; Galimberti et al., 1987; Hopping, 1976; Lai et al., 1989; Lawes and Woolley, 1987; Pyke and Alspach, 1986; Snelgar and Hopkirk, 1988), the decrease in fruit mass seems to be due to insufficient pollination rather than to competition for nutrients. Number of buds per male vine was proportional to the covered area so that the number of male buds per hectare were equivalent for all treatments. As a consequence, the male : female flower ratio was higher in treatments with fewer buds per hectare.

To understand bud efficiency variations, the percentage of fruitful buds, the number of corymbs per fruitful shoot, the number of flowers per corymb, and the flower and fruit drop must be examined individually. The percentage of fruitful buds decreased slightly with increasing bud number per hectare (Fig. 3 ). The number of floral corymbs per shoot was maximum at 100,000 to $150,000 \mathrm{buds} / \mathrm{ha}$ and then declined. The number of flowers per corymb was constant and equal to 1.00 because nearly all of the leaf axils bore a single flower. The cumulative

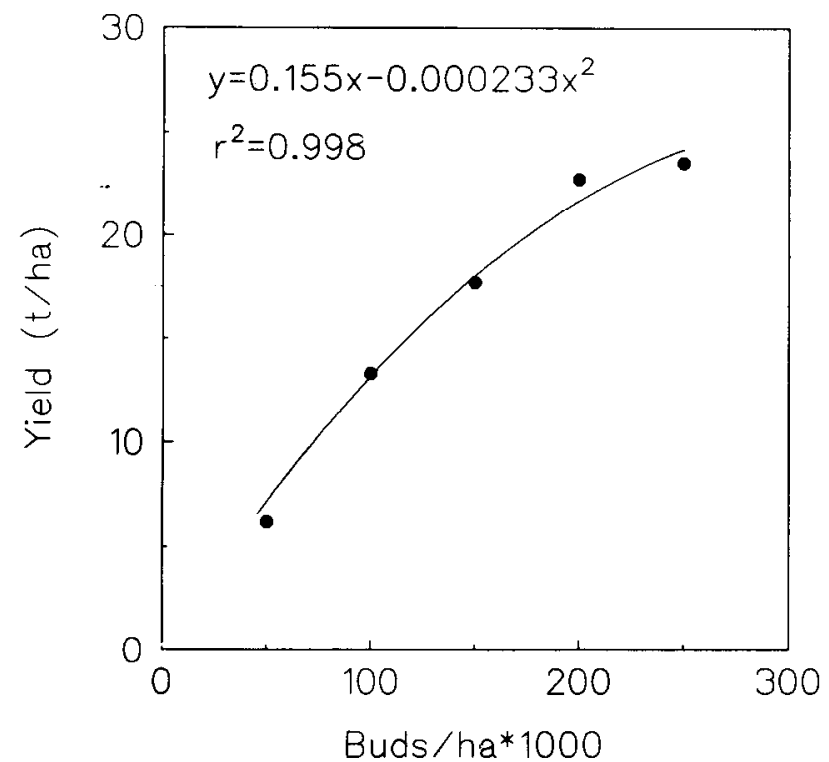

Fig. 1. Influence of bud number per hectare on yield of 'Hayward' kiwifruit. Each point is the mean of 40 observations.

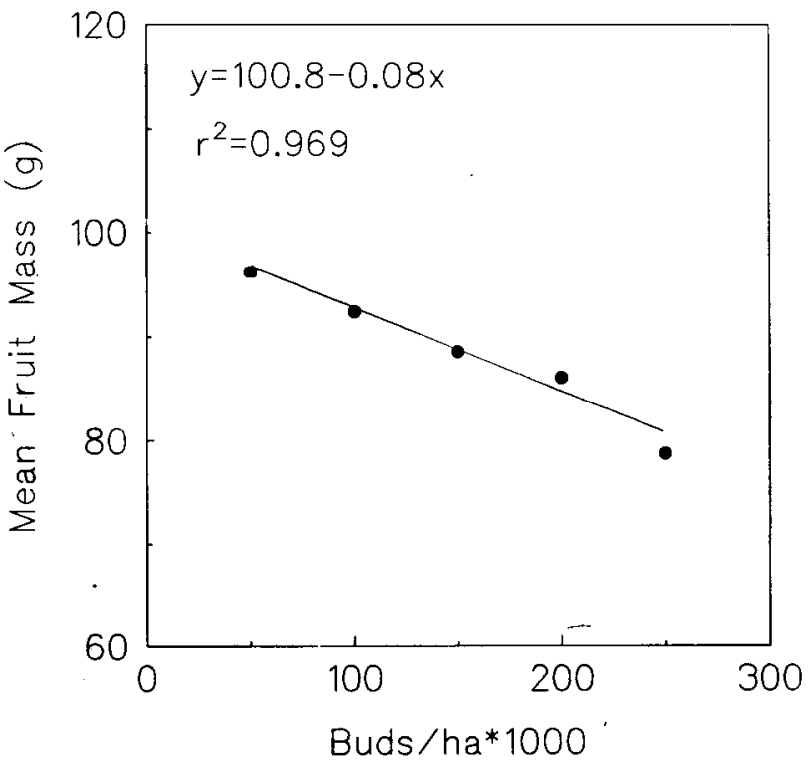

Fig. 2. Influence of bud number per hectare on mean fruit mass of 'Hayward' kiwifruit. Each point is the mean of 40 observations.

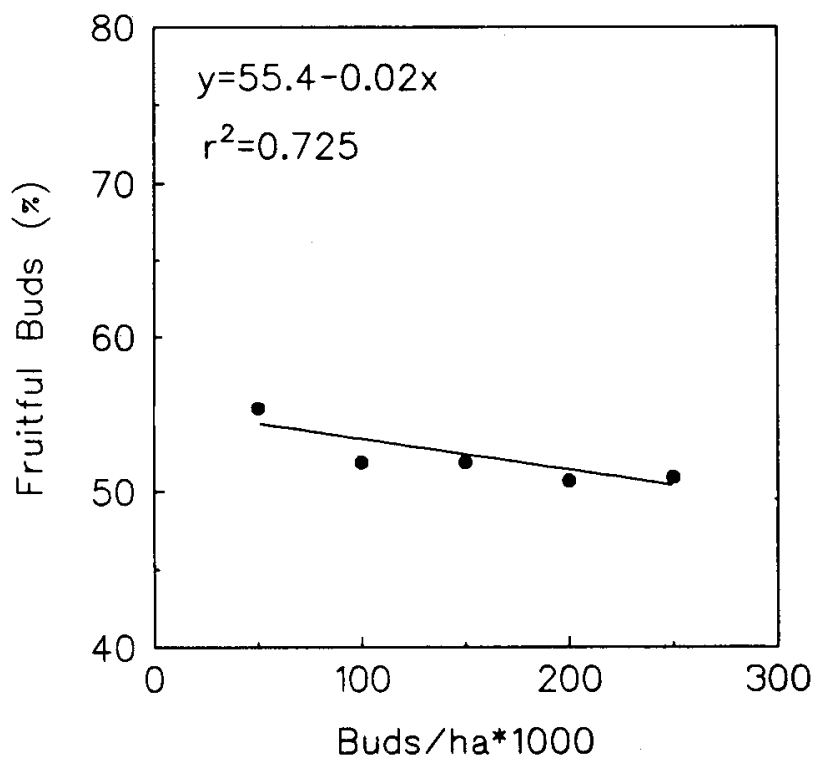

Fig. 3. Influence of bud number per hectare on fruitful budbreak in 'Hayward' kiwifruit. Each point is the mean of 160 observations from 40 vines.

drop in flowers and fruit was $4 \%$, with no differences among treatments. Consequently, the data concerning the number of flowers per corymb and the flower and fruit drop are not reported and the number of fruits per fruitful shoot is shown instead of the number of corymbs per fruitful shoot (Fig. 4). The number of fruits per fruitful shoot showed the same trend as the number of corymbs per fruitful shoot, as would be expected.

Variations in the percentage of reproductive buds and in the number of fruits per fruitful shoot could be due to competition or inhibition among the buds, as hypothesized by Grant and Ryugo (1982). In addition, fruiting wood with few buds per hectare was selected more accurately than wood with more buds. At high bud numbers, nearly all of the available canes were sometimes required to reach the necessary count. Saving vigorous or not completely mature canes in plots with high bud numbers led to a lowering of the mean bud fertility in them. 


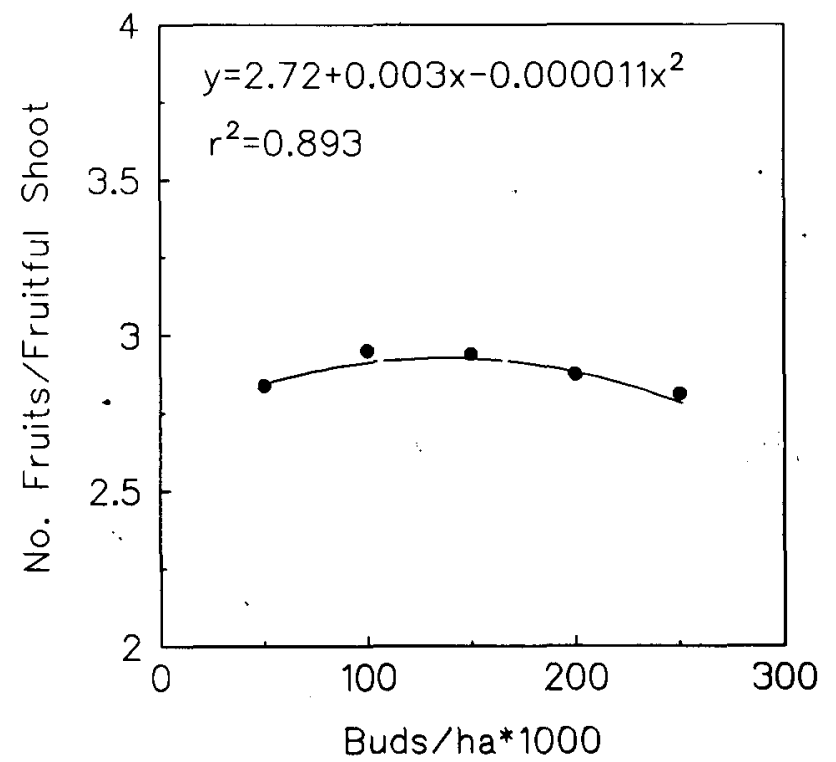

Fig. 4. Influence of bud number per hectare on the number of fruits per fruitful shoot in 'Hayward' kiwifruit. Each point is the mean of 160 observations from 40 vines.

Table 1. Influence of in-row spacing on cropping of 'Hayward' kiwifruit.

\begin{tabular}{|c|c|c|c|}
\hline \multirow{2}{*}{$\begin{array}{l}\text { In-row } \\
\text { spacing } \\
\text { (m) }\end{array}$} & \multicolumn{2}{|c|}{ Yield $^{2}$} & \multirow{2}{*}{$\begin{array}{c}\text { Mean } \\
\text { fruit } \\
\text { mass } \\
(\mathrm{g})\end{array}$} \\
\hline & (kg/vine) & $\left(\mathrm{t} \cdot h \mathrm{~h}^{-1}\right)$ & \\
\hline 1.5 & 13.5 & 17.5 & 94 \\
\hline 3.0 & 26.8 & 17.3 & 89 \\
\hline 4.5 & 37.8 & 16.3 & 87 \\
\hline 6.0 & 48.3 & 15.6 & 84 \\
\hline Linear & $*$ & $*$ & $*$ \\
\hline
\end{tabular}

${ }^{2}$ Mean of five bud number treatments per hectare and 2 years.

*Significant at $P=0.05$.

Below 100,000 buds/ha, the" number of fruits per shoot tended to decrease because severe pruning enhanced the vegetative vigor to the detriment of cane fruitfulness (Grant and Ryugo, 1982).

Crop load declined slightly as in-row spacing increased from 1.5 to $6.0 \mathrm{~m}$ (Table 1 ). This trend mainly is attributable to the proportional reduction of fruit mass with an increase in vine inrow distances (Table 1). The adverse effect of the low plant densities on fruit mass maybe due to the excessively wide area that was served by a single pollenizer in these plots. In the lowest plant density, there were only 46 pollenizers/ha, each one providing pollen for a $217-\mathrm{m}^{2}$ area. The number of pollenizers rose with increasing plant density and the closest spacing had 185 male plants/ha, each one covering only a $54-\mathrm{m}^{2}$ area. Although the total amount of pollen per hectare was the same for all the plant densities because of the same male : female ratio and the constant bud number per square meter for male plants, the probability of the female flowers farthest from the pollen source being fertilized was lower in the low plant densities than at the highest densities because of greater distances from the pollenizer (Clinch, 1982).

The percentage of fruitful buds did not vary among the different plant densities (Table 2). The number of fruits per shoot increased from the closest spacing to the widest, but the differences among the treatments were no greater than $3 \%$.

Fruit yield was slightly different in the 2 years, whereas var-
Table 2. Influence of in-row spacing on flowering and fruiting 'Hayward' kiwifruit.

\begin{tabular}{|c|c|c|c|c|}
\hline \multirow{2}{*}{$\begin{array}{l}\text { In-row } \\
\text { spacing } \\
(\mathrm{m})\end{array}$} & \multicolumn{3}{|c|}{ Buds } & \multirow{2}{*}{$\begin{array}{c}\text { Fruits/ } \\
\text { fruitful } \\
\text { shoot } \\
\text { (no.) }\end{array}$} \\
\hline & $\begin{array}{c}\text { Inactive } \\
(\%)\end{array}$ & $\begin{array}{c}\text { Vegetative } \\
(\%)\end{array}$ & $\begin{array}{c}\text { Fruitful } \\
(\%)\end{array}$ & \\
\hline$\overline{1.5}$ & 37 & 13 & 50 & 2.8 \\
\hline 3.0 & 38 & 12 & 50 & 2.9 \\
\hline 4.5 & 38 & 8 & 54 & 2.9 \\
\hline 6.0 & 39 & 8 & 53 & 3.0 \\
\hline Linear & NS & $*$ & NS & $*$ \\
\hline
\end{tabular}

"Mean of five bud number treatments per hectare and 2 years.

yInactive includes dead and dormant buds.

NS, *Nonsignificant or significant at $P=0.05$, respectively.

Table 3. Influence of years on fruiting and bud type in 'Hayward' kiwifruit. Average of all treatments.

\begin{tabular}{|c|c|c|c|c|c|c|}
\hline \multirow[b]{2}{*}{ Year } & \multirow[b]{2}{*}{$\begin{array}{c}\text { Yield } \\
\left(\mathrm{t} \cdot \mathrm{ha}^{-1}\right)\end{array}$} & \multirow{2}{*}{$\begin{array}{c}\text { Mean } \\
\text { fruit } \\
\text { mass } \\
(\mathrm{g})\end{array}$} & \multicolumn{3}{|c|}{ Buds } & \multirow{2}{*}{$\begin{array}{l}\text { Fruits } \\
\text { fruitfu } \\
\text { shoot } \\
\text { (no.) }\end{array}$} \\
\hline & & & $\begin{array}{c}\text { Inactive }^{z} \\
(\%)\end{array}$ & $\begin{array}{c}\text { Vegetative } \\
(\%)\end{array}$ & $\begin{array}{c}\text { Fruitful } \\
(\%)\end{array}$ & \\
\hline 1987 & 16.2 & 96 & 37 & 15 & 48 & 2.7 \\
\hline 1988 & 17.1 & 81 & 39 & 6 & 55 & 3.1 \\
\hline Significance & $*$ & $*$ & $*$ & $*$ & $*$ & $*$ \\
\hline
\end{tabular}

Inactive includes dead and dormant buds.

* Significant at $P=0.05$.

iations of the mean fruit mass, as well as the percentage fruitful budbreak, were more appreciable (Table 3). Nevertheless, such variations seem due to environmental conditions. In contrast, interactions between treatments and years were not significant, suggesting that kiwifruit is not a biennial bearer if severely pruned or if overcropped (Testolin et al., 1988).

The downward trend in 'Hayward' kiwifruit crop response to increasing bud number per hectare is similar to that reported previously (Testolin et al., 1988). Nevertheless, the yield found in the present research is on average $=4490$ lower than that of the previous work. This reduction probably occurred because of the small fruit size and low number of fruits per fruitful shoot that characterized the orchard in which the present experiment was carried out. The small fruit size is not unusual and occurs whenever pollination is inadequate. The number of fertile axils per fruitful shoot (2.8 on average) is less than the 3.1 to 5.6 'range typical for temperate zones (Blanchet, 1985; Brundell, 1975; Di Lorenzo et al., 1987; Giorgio et al., 1987; Grant and Ryugo, 1984; Snelgar, 1988; Snelgar et al., 1988; Testolin et al., 1985; Zhang and Thorp, 1986). Low bud fruitfulness in this study is unusual, but the results are in agreement with previous research (Testolin et al., 1988).

In-row spacings had a small effect on determining crop load in mature kiwifruit orchards. Because close spacings (1.5 and $3.0 \mathrm{~m}$ ) cropped better than wide spacings in the first 5 years after planting (Testolin et al., 1987), a 3.0-m in-row spacing seems to be the most suitable distance for kiwifruit. Closer spacings do not increase yields at any time. At wider spacings, full production is reached later (Testolin et al., 1987).

\section{Literature Cited}

Blanchet, P. 1985. Fertilité et croissance du kiwi (Actinidia chinensis Pi.). Fruits 40(10):647-658.

Blanchet, P. 1986. La taille longue du kiwi (varieté Hayward) (Long pruning of kiwifruit (cultivar Hayward)). Arbor. Fruit. 32(380):4749. 
Brundell, D.J. 1975. Quantitative aspects of flowering in the Chinese gooseberry (Actinidia chinensis Planch.). New Zealand J. Agr. Res. 18:371-374.

Buwalda J.G. and G.S. Smith. 1988. A mathematical model for predicting annual fertiliser requirements of kiwifruit vines. Scientia Hort. 37:71-86.

Clinch, P.G. 1982. Some factors influencing the pollination of kiwifruit by honeybees. Proc. Kiwifruit Seminar, Hamilton and Tauranga, New Zealand. p. 26-29.

Clinch, P.G. 1984. Kiwifruit pollination by honeybees. 1. Tauranga observations 1978-81. New Zealand J. Expt. Agr. 12:29-38.

Costa, G., F. Succi, R. Biasi, and O. Miserocchi. 1987. Vegetative and cropping performance of kiwifruit (cv. Hayward) as related to pruning length and bud number. Proc. First Intl. Symp. Kiwi, Padova, Italy, 14-16 Oct.

D’Ambrosio, M., F. Intoppa, and M.G. Piazza. 1986. Indagini preliminari sull'attivitá impollinatrice delle api nei confronti di Actinidia chinensis Planch. Apicoltura 2:155-164.

Di Lorenzo, R., L. Di Marco, A. Raimondo, and P. Inglese. 1987. Survey of kiwifruit (Actinidia deliciosa) flowering and fruiting behaviour in some areas of southern Italy. Proc. First Intl. Symp. Kiwi, Padova, Italy, 14-16 Oct.

Doorenbos, J. and W.O. Pruitt. 1977. Crop water requirement. FAO Irrigation and Drainage Paper 24.

Galimberti, P., M. Marro, and J. Youssef. 1987. Periodo utile d'impollinazione in Actinidia chinensis (Planch.). Frutticoltura 49(1):5 154.

Giorgio, V., A. Standardi, and R. Testolin. 1987. Flowering and fruiting in pergola-trained kiwifruit. Proc. First Intl. Symp. Kiwi, Padova, Italy, 14-160 ct.

Grant, J.A. and K. Ryugo. 1982. Influence of developing shoots on flowering potential of dormant bud of Actinidia chinensis. HortScience 17(6):977-978.

Grant, J.A. and K. Ryugo. 1984. Influence of within-canopy shading on fruit size, shoot growth, and return bloom in kiwifruit. J. Amer. Soc. Hort. Sci. 109(6):799-802.

Hopping, M.E. 1976. Effect of exogenous auxins, gibberellins, and cytokinins on fruit development in chinese gooseberry (Actinidia chinensis Blanch.). New Zealand J, Bet. 14:69-75.

Lai, R., D.J. Woolley, and G.S. Lawes. 1989. Retardation of fruit growth of kiwifruit (Actinidia deliciosa) by leaves: Interactions with vine performance and seed number. Scientia Hort. 39:319-329.

Lawes, G.S. and D. J. Woolley. 1987. Seeds and other factors affecting fruit size in kiwifruit. Proc. First Intl. Symp. Kiwi, Padova, Italy, 14-16 Oct.

Linsley-Noakes, G.C. and P. Allan. 1987. Effect of winter temperatures on flower development in two clones of kiwifruit (Actinidia deliciosa (A. Chev.) C.F. Liang et A.R. Ferguson). Scientia Hort. 33:249-260.

Pyke, N.B. and P.A. Alspach. 1986. Inter-relationship of fruit weight, seed number and seed weight in kiwifruit. New Zealand J. Agr. Sci. 20:153-156.

Snedecor, G.W. and W.G. Cochran. 1980. Statistical methods. 7th ed. Iowa State Univ. Press, Ames.

Snelgar, W.P. 1988. The effect of cane orientation on flower production in kiwifruit (Actinidia deliciosa). J. Hort. Sci. 63(2):341-347.

Snelgar, W. P., G.S. Bayley, and P.J. Manson, 1988. Temperature studies on kiwifruit vines using relocatable greenhouses. New Zealand J. Expt. Agr. 16:329-339.

Snelgar, W.P. and G. Hopkirk. 1988. Effect of overhead shading on yield and fruit quality of kiwifruit (Actinidia deliciosa).J. Hort. Sci. 63(4):731-742.

Snowball, A. and J. Considine. 1986. Flowering in kiwifruit (Actinidia deliciosa)Liang et Ferguson): Positional effects and development. Acta Hort. 175:85-89.

Testolin, R., R. Messina, and E. Peterlunger. 1987. Kiwifruit growth and yield as affected by in-row spacing. Proc. First Intl. Symp. Kiwi, Padova, Italy, 14-16 Oct.

Testolin, R., R. Messina, and J. Youssef. 1985. Indagine sulla fertilitá dell' actinidia (Flowering and fruiting in the kiwifruit (Actinidia chinemis Planch.)). Frutticoltura 47(5):59-64.

Testolin, R., J. Youssef, and A. Galliano. 1988. La potatura dell'actinidia. Studio dells carica di gemme e dells lunghezza dei tralci (Kiwifruit pruning. A study on bud load per surface unit and per cane). Frutticoltura 50(11):53-57.

Zhang, J. and T.G. Thorp. 1986. Morphology of nine distillate and three staminate New Zealand clones of kiwifruit (Actinidia deliciosa (A. Chev.) C.F. Liang et A.R. Ferguson var. deliciosa). New Zealand J. Bet. 24:589-613. 